\title{
The First Spring Flower
}

\section{Dr. George Ledingham, Saskatoon}

THIS story started late last fall as a mistake and a violation of conservation of one of our native plants. It ended early this spring as a joyous experience in appreciation of natural beauty which we would like to share with every one who reads the Blue Jay.

Early last October two roots of the Stemless Lady's Slipper were brought to me from Lac la Ronge. 'The leaves and flower stalk were dead and brown, but the roots are perennial so they were potted and kept in the potato cellar until the middle of March. Early this spring, each root sent up a fat bud and we could wait no longer and brought the pot up to light and warmth. Growth was rapid, and soon the plants were complete with two leaves and one flower each, as shown in the picture.

The Stemless Lady's Slipper is unlike all other Lady's Slippers in three main respects. These differences are so striking that Small separated this species out of the genus Cypripedium and called it Fissipes acaulis. In the first place, it is without a true stem, the two leaves and flowering stalk coming from below the surface of the ground. In the second place, it grows in dry, rocky exposed places. Its growth is limited and it flowers early, frequently in April in the south-eastern part of its range. In Saskatchewan, it occurs in the far north on Precambrian rock, and there it does not flower till after the middle of June. In the third place, as stressed by Small, the toe of the slipper is split on top. This means that the bee will enter well forward between the two halves of the lip and then climb up to his reward. As he rises, his head and back will brush against, and leave pollen on, the moist, roughish stigma. Above, and on either side of the column which bears the stigma, are two round openings by which the insect may leave the slipper. The upper side of each exit is a fertile anther. The back of the bee is covered with pollen as he climbs out and says goodbye.

After several days of enjoyment of:

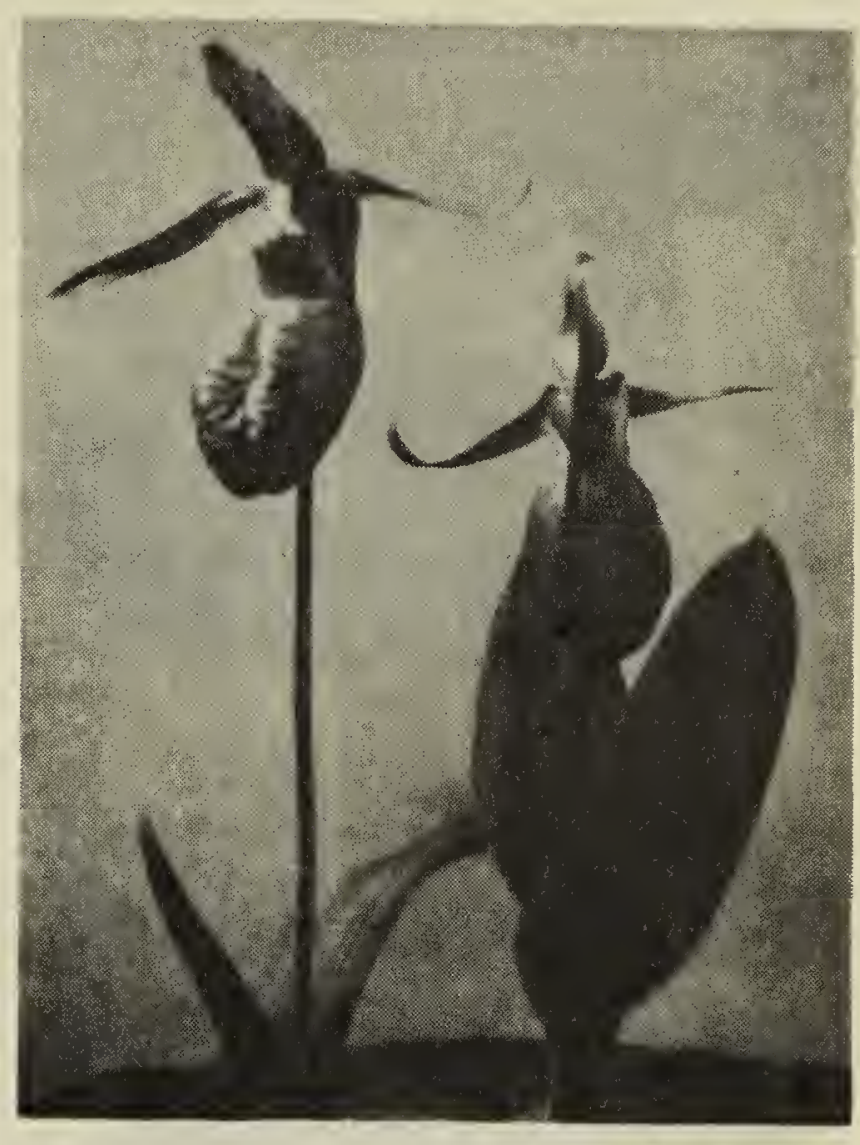

-PMoto DY L. G. EAUndens

these floral harbingers of spring, we tock them to the Biology Department of the University to share them with our associates. It was then that Dr. L. G. Saunders took the picture which we are sharing with you. The last days of these two flowers were spent with our honorary president and his wife.

\section{OILING UP}

\section{Elizabeth Barker, Regina}

Although I have, at various times seen small birds working over the soles of their feet, I never realized until a few short weeks ago that they oil them with as much care as they bestow on their feathers.

The bird in question was a male House Sparrow, perched on a stick outside my window, cleaning himself up. He would draw a beakful of oil, oil perhaps a wing top or part of his tail, then go at the underside of his spread out foot and work carefully up and down each toe in turn, finishing up with some feathers. Then back for more oil-repeat the same process over and over (three times in this case) till the job was complete. 